\title{
Treatment of COVID-19 with Herbal Medicines: Perceptions, Attitudes and Practices of Healthcare Professionals Students in Uganda
}

Blaise Kiyimba ( $\sim$ blaisekiym12@gmail.com )

Makerere University

Andrew Marvin Kanyike

Busitema University

Nelson Ssewante

Makerere University

Racheal Nalunkuma

Makerere University

Phillip Musoke

Makerere University

Linda Atulinda

Makerere University

Claire Namuwaya

Makerere University

Nicholas Kisaakye Wamala

Kampala International University

Teddy Onyait

Makerere University

Ramona Noeline Aringo

Mbarara University of Science and Technology

Hussein Kato

Makerere University

Ignatius Asasira

Makerere University

Felix Bongomin

Gulu University

\section{Research Article}

Keywords: Herbal medicine, COVID-19, Treatment, Healthcare, Students, Uganda

Posted Date: September 14th, 2021

DOI: https://doi.org/10.21203/rs.3.rs-900238/v1 
License: (1) (1) This work is licensed under a Creative Commons Attribution 4.0 International License. Read Full License 


\section{Abstract}

Background: Use of herbal medicine (HM) for the treatment and prevention of the coronavirus disease -2019 (COVID19) has been reported worldwide. In this study, we aimed to assess the perceptions, attitude and practices of healthcare professionals (HP) students in Uganda concerning HM use in the management of COVID-19 illness.

Methods: We conducted an online, cross-sectional study using quantitative methods among HP students across the 12 medical schools in Uganda. Undergraduate HP students aged 18 years and older, from $1^{\text {st }}$ to $5^{\text {th }}$ year of study, pursuing various programs were recruited. Blooms cut-off of $80 \%$ (score of $\geq 24 / 30$ ) was used to determine good perception and a positive attitude towards $\mathrm{HM}$ use. Logistic regression analysis was performed to determine factors associated with HM use.

Results: A total of 350 participants responded. Of this, $223(63.7 \%)$ were male. The median age of all participants was 23 (IQR=19-56) years. Majority ( $n=234,66.9 \%)$ were pursuing Bachelor of Medicine and Bachelor of Surgery (MBChB). All participants reported awareness on HM use in the management of COVI-19. Fifty-four (15.4\%) respondents had a good perception towards HM use, with students in their first year of study having 3-fold the odds of having good perception compared to those in their fifth year (aOR: 2.9, 95\% C. I: 1.1-8.1, p=0.037).

Participants pursuing Bachelor of Pharmacy (BPHAR) had 4.2-fold higher odds of having a positive attitude towards HM use compared to those pursuing MBChB (aOR: 4.2, 95\% Cl:1.8-9.9, p=0.001) and those in first year had 2.7-fold higher odds of having a positive attitude towards $\mathrm{HM}$ use compared to participants in fifth year of study. (aOR=2.7, $95 \% \mathrm{Cl}=1.2-6.3, \mathrm{p}=0.019)$. Participants with positive attitude towards $\mathrm{HM}$ use $(\mathrm{aOR}=63.7,95 \% \mathrm{Cl}=12.8-316.4$, $\mathrm{p}<0.001)$, pharmacy students $(\mathrm{aOR}=2.6,95 \% \mathrm{Cl}=1.1-6.4, \mathrm{p}=0.035)$, allied health program students $(\mathrm{aOR}=3.6,95 \%$ $\mathrm{Cl}=1.1-11.6, \mathrm{p}=0.032)$, those with good perception ( $\mathrm{aOR}=3.3,95 \% \mathrm{Cl}=1.6-6.5, \mathrm{p}<0.001)$ and positive attitude (aOR=2.7, $95 \% \mathrm{Cl}=1.2-5.9, \mathrm{p}=0.013$ ) were more likely to recommend use of HM in the management of COVID-19.

Conclusion: Awareness of HM use was universal among the participants. However, despite a high proportion of the participants reporting negative perception and attitude towards HM use, at least one- third use HM when they had COVID-19.

\section{Introduction}

The Coronavirus disease 2019 (COVID-19) caused by the novel severe acute respiratory syndrome corona-virus-2 (SARS-COV-2) is an important global public health challenge [1]. To date, there is no approved definitive treatment for the disease, with dexamethasone, tocilizumab and other monoclonal antibodies being among the most promising management armamentarium [2-3]. The major breakthrough attained so far is the discovery of COVID-19 vaccines with at least one of the vaccine candidates being approved by the United States Foods and Drugs Administrations [4].

Since the beginning of the COVID-19 pandemic, several countries across the world embraced the use of herbal medicine (HM) for the prevention of treatment of COVID-19 [5-7]. The incorporation of HM use in COVID-19 treatment has been especially more embraced by Asian countries which earlier experienced its effectiveness in their previous epidemics and officially adopted it as one of their treatment modalities [8-10]. Clinical evidence from a range of studies has shown significant benefits of HM in the treatment of viral diseases with COVID-19 inclusive [6-7,11-12]. In China, a study to compare a combined therapy of western medicine and HM (CT) to western medicine alone (WM) in the treatment of COVID-19 reported the CT to have had outstanding quick effects in relieving cough, fever, dry and 
sore throat with no serious adverse events. ${ }^{6}$ and improved lung computed tomography scan manifestations [13] compared to WM alone.

In June 2021, the Uganda National Drug Authority (NDA) approved the HM sold under the tradename "COVIDEX" for the management of viral illnesses, including COVID-19 [14]. Since then, its demand on market has overwhelmed its supply than any other drug in the country [15]. Since the approval of COVIDEX, there have been mixed opinions about its use not only among some HP workers but also the patients [16]. This leaves the public with a big question of whether to resort to the new COVIDEX and other HMs and leave WM, remain on WM alone, or use a combination of $\mathrm{HM}$ and WM for better treatment outcomes.

Given the current situation where majority of COVID-19 patients are under home-based care, with all HP students at home due to schools' closure, these students are expected to be the first line source of medical advice to patients with COVID-19 in their communities, hence play a crucial role on the use of HM in the communities countrywide. It is therefore imperative to know the views of HP students towards HM. However, to our knowledge, very few studies have been conducted to find out the HP students' perspectives regarding HM use especially in Africa. This study therefore aimed to investigate the perception, attitude, and practices of Ugandan HP students towards HM use to provide evidence-based data that can be used to set appropriate interventions to ensure that they carry a uniform and safer advisory message concerning $\mathrm{HM}$ use for better patient guidance and best treatment outcomes in the country and worldwide.

\section{Methods}

\section{Study design}

Between $9^{\text {th }}$ August 2021 and 23rd August 2021, we conducted an online, descriptive cross-sectional study using quantitative technique.

\section{Study setting}

This study was conducted in Uganda. There are currently 53 universities in Uganda turning out over 40,000 graduates annually [17]. However, only 12 universities offer HP courses with an estimated population of 10,000 students. These include Makerere University (Mak), Mbarara University of Science and Technology (MUST), Busitema University (BU), Gulu University (GU), Kabale University, Kampala International University (KIU), King Ceasor University, Islamic University in Uganda (IUIU), Uganda Christian University (UCU), Soroti University, Muni University and Lira University (LU).

\section{Target population}

All university students male and female, 18 years or older, from first to fifth years of study offering health care programs at any of the above 12 medical schools in Uganda. Programs that participated include Bachelors in Medicine and surgery (MBChB), Bachelor in Pharmacy (BPHAR), Bachelor in Nursing/ Midwifery (BSN/MW), Bachelor in Dental surgery (BDS), Bachelor in Public health/ Environmental health (BPH), Bachelor in medical Radiography (BMR), Bachelors of science in Anesthesia among others.

\section{Sample size}


The sample size was calculated using Epi Info StatCalc by the Center for Disease Control (CDC) for population surveys. With an estimated population size of 10,000 health care students in Uganda at expected frequency of $50 \%$ and confidence limits of $4.0 \%$, the estimated sample size at $95 \%$ confidence interval was 566 students.

\section{Sampling procedure}

We used convenience sampling method, whereby those who were able to access the link to the online survey questionnaire sent out were involved. We identified all relevant WhatsApp, telegram and email groups of HP students through a coordinator at each university and continuously shared the invitation link to the online questionnaire.

\section{Study Variables}

Dependent variables included questions on perceptions, attitudes and practices concerning herbal medicine use in the treatment of COVID-19. The independent variables included age, sex, rural or urban setting of growing up, religion, year of study, program and University of study.

\section{Data collection tool.}

The questionnaire used was adopted from two different pre-validated questionnaires used by two related studies [1819] and were modified to suit our study setting and objectives. The tool consisted of four sections;

Section I: Had 7 questions which we used to assess for the HP students' socio-demographic factors including age, sex, religion, growing up setting, academic year, program and University of study.

Section II: 6 questions were used to assess HP students' perceptions regarding HM use in COVID-19 treatment by indicating YES, NO, or IAM NOT SURE against a given statement. The questions were adopted from Alotiby et al [18].

Section III: Had 6 questions, each scored on a 5 Likert scale ranging from strongly agree, agree, neutral, disagree, and strongly disagree. It was used to assess students' attitude towards HM use in COVID-19 treatment. The questions were adopted from Samara et al [19].

Section IV: Had 10 questions used to assess the students' practices and use of HM in COVID-19 treatment. The questions were adopted from Samara et al [19] and some were added by the investigators.

\section{Quality Control}

Questions were designed in simple English words for effective understanding by the participants. Soft copies of the questionnaires were designed with checks to allow valid and complete entries only. The questionnaire was pretested among 15 veterinary medicine students and all required changes were made before sending it out to the final participants.

\section{Data management and analysis.}

Fully completed questionnaires were extracted from Google Forms and exported to Microsoft Excel 2016 for cleaning and coding. The cleaned data was exported to STATA 15 for analysis. Numerical data was summarized as means and standard deviations (SD) or median and interquartile range (IQR). Categorical data was summarized as frequencies and proportions. Blooms cut-off of $80 \%$ was used to determine whether or not a participant had good perception, positive attitude. Perception was assessed using 6 questions and each correct answer scored 1 point. Attitudes were assessed using a 5-point Likert-item questions with responses including strongly disagree, disagree, 
neutral, agree and strongly agree and the scores were 1-5 for the respective responses. The total score was 30 , and a score of $\geq 24$ ( $\geq 80 \%$ ) was considered a positive attitude. Associations between independent variables and dependent variables were assessed using Chi-square and Fischer's exact test. Binary logistic regression analysis model was constructed. We accounted for important confounders in the model. Data was presented as adjusted odds ratio $(\mathrm{aOR})$ and $95 \%$ confidence interval $(95 \% \mathrm{Cl})$. All data analyses were two-tailed and $p<0.05$ was considered statistically significant.

\section{Results}

Of the anticipated 566 responses, a total of 363 responses were received. After excluding duplicates, data of 350 (response rate, 62\%) was finally analyzed.

\section{Sociodemographic characteristics}

Of the 350 respondents, $63.7 \%(n=223)$ were male. The median age was 23 years (IQR=19-56). Majority $(41.1 \%$, $\mathrm{n}=144)$ of the participants were from Makerere University. Most of the respondents $(54.6 \%, n=191)$ had grown up from urban settings and $66.9 \%(n=234)$ were pursuing MBChB. The rest of the demographics are as summarized in table 1.

\section{Perception towards use of herbal medicine}

Fifty-four (15.4\%) participants had a good perception towards HM use in COVID-19 management, with an overall mean score of $54.9 \pm 21.2 \%$. 293 (83.5\%) participants believed that HMs can improve the health of COVID-19 patients. The year of study was the only demographic factor significantly associated with having a good perception, Table 1. Students in the first year of study had 2.9-fold higher odds of having a good perception towards HM use compared to those in fifth year (aOR: 2.9, 95\% C. I: 1.1-8.1, p=0.037), Table 2.

\section{Attitude towards herbal medicine use.}

One hundred and twenty-nine (36.9\%) participants had a positive attitude towards HM use for the treatment of COVID-19 t. The mean score was $72 \pm 13.6 \% .298$ (85.2\%) participants believed that it is necessary for a health practitioner to have a good knowledge of HM use in COVID-19 management and 256 (73.1\%) agreed that it is important to incorporate course units on HM use in their medical school curricula. The course $(p<0.001)$ and year of study $(p=0.003)$ were strongly associated with positive attitudes, Table 1.

Participants pursuing BPHAR had 4.2-fold higher odds of having a positive attitude towards HM use compared to those pursuing MBChB (aOR: 4.2, 95\% Cl:1.8-9.9, p=0.001) and those in first year had 2.7-fold higher odds of having a positive attitude towards HM use compared to participants in fifth year ( $\mathrm{OOR}=2.7,95 \% \mathrm{Cl}=1.2-6.3, p=0.019)$.

\section{Practices and use of $\mathrm{HM}$}

All participants reported awareness on HM use in the management of COVI-19. Covidex (97.7\%) and cooked plant leaves (66.9\%) were both the most known HMs to all the participants and the most used by those who had tested positive for COVID-19. Social media was the major source of awareness for HM use in COVID-19 treatment to majority $(68.8 \%, \mathrm{n}=238)$ of participants. 43 (37.1\%) of those who had tested positive for COVID-19 had used HM. In addition, 207 (69.7\%) participants had advised either a friend or relative to use HM for COVID-19 treatment and 238 (93.7\%) would advise HM use in combination with WM. The most recommended HM was Covidex $(64.7 \%, n=134)$ and the two major factors considered by participants to recommend use of a specific brand of HM were (1) Getting a 
positive response from patients following its use $(70.9 \%, n=248)$ and (2) If the drug was of approved efficacy $(62 \%$, $\mathrm{n}=217)$.

Testing positive for COVID-19 was associated with an increased chance of using HM $(p<0.001)$. Similarly, the year of study $(p=0.009)$, having good perception $(p=0.001)$, and a positive attitude $(p<0.001)$ were significantly associated with increased likelihood of recommending a HM for friends and relatives, Table 4.

Participants who had positive attitude towards HMs were more likely to personally use them (aOR=63.7, 95\% $\mathrm{Cl}=12.8-316.4, \mathrm{p}<0.001)$. Likewise, Pharmacy students ( $\mathrm{aOR}=2.6,95 \% \mathrm{Cl}=1.1-6.4, \mathrm{p}=0.035)$, those on other allied health programs $(\mathrm{aOR}=3.6,95 \% \mathrm{Cl}=1.1-11.6, \mathrm{p}=0.032)$, those with good perception $(\mathrm{aOR}=3.3,95 \% \mathrm{Cl}=1.6-6.5$, $\mathrm{p}<0.001)$ and positive attitude $(\mathrm{aOR}=2.7,95 \% \mathrm{Cl}=1.2-5.9, \mathrm{p}=0.013)$ were more likely to recommend use of $\mathrm{HM}$ in the management of COVID-19, Table 5.

\section{Discussion}

In the current space of no established curative medicine for COVID-19, development and use of HM has taken stage in the race to find a cure for COVID-19 in most countries, especially in Africa and Asia where herbal remedies have for long been used for many other diseases and previous disease outbreaks [20]. In Uganda, a number of these HMs are being fronted as beneficial from anecdotal reports of patients that have used them, creating contention among the general public on their safety and usage since majority have few or even no clinical trials conducted on them. Most studies around the globe have assessed the take of HP students on the general complementary and alternative medicines (CAM) use and this is among the very first few studies to explore the subject matter among the same group but specifically in relation to COVID-19 treatment in Africa.

In this study, there was a small proportion of participants (15.4\%) with good perception towards HM use in Covid-19 management. This is possibly because the CAM methods are not generally taught in Ugandan medical schools therefore students tend to trust more the WM which is part of their curricula. This is in contrast with findings reported in Palestine [19] Bangladesh [21] and Minnesota [22] that reported very good perceptions by students towards HM use. Students in the first year of study were twice more likely to have good perception towards HM use compared to those in fifth year and also had more positive attitudes than those in higher years. This is possibly because students in higher medical classes have studied much more about the process of drug discovery and pharmacology during their years in medical school and may tend to trust more a drug that has undergone all the stages of clinical trials which is not the case for most of the HMs in Uganda. This finding is congruent with those reported by Samara and colleagues [19], Akan et al [23] and Bai et al [24] which revealed very good knowledge and attitude concerning HM by students in lower years of study compared to those in upper years. However, with the increasing reported evidence of significant benefits from use of HMs globally in the treatment of viral diseases including COVID-19 [25-26] incorporation of training on CAMs may be warranted in Uganda's medical schools to redefine these perceptions.

About one-third (36.9\%) of the participants had a positive attitude towards HM use in COVID-19 treatment. This is lower than that reported among Palestine medical students among which two thirds had a positive attitude towards use of CAM methods like HM [19]. This is possibly because the use of HM has been entrenched in many Asian countries' health care (HC) systems and has also been used in previous epidemics like SARS [20]. Despite this negative attitude, over two thirds of respondents (83\%) acknowledged the necessity for every HP to have a good knowledge concerning HM use and about two thirds (73.1\%) recommended the incorporation of HM use training into their medical curricula. This finding is in agreement with many previous studies [21-22, 25, 27]. This could imply possible dilemma HP students usually face in drawing a clear-cut line between WM and HM and significant 
challenges in making decisions while advising patients on $\mathrm{HM}$ use hence introducing courses on $\mathrm{HM}$ use in their training could reduce on this confusion and establish a relatively common ground for all for better patient guidance.

Participants pursuing BPHAR were twice more likely to have positive attitude than those pursuing MBChB. Pharmacy students usually interface more with training in CAMs through course units such as pharmacognosy during their medical school training than those of MBChB and it could explain their better attitude. This result corelates with findings reported in Minnesota [22] Sierra Leon [24] and Pakistan [27] which reported good attitude towards CAMs among BPHAR students. In this study the male students had a better attitude compared to the female counterparts conversely to a number of various studies [28-29] assessing attitude towards CAMs. However, this isn't surprising given our previous experiences from studies related to COVID-19 disease and its vaccine acceptability among Ugandan medical students where females have consistently exhibited a negative attitude [30].

In this study, there was a high prevalence (69.7\%) of advising relatives or friends to use HM for covid-19 treatment by the respondents and more than 9 in every $10 \mathrm{HP}$ students would advise combination therapy of WM and HM as the format of HM use. This is critical because with HMs of unknown pharmacological profiles, significant drug-drug interactions from this combination could result in undesirable adverse drug reactions. It could also signify lack of confidence on which of the two modalities WM or HM is better, hence students might have prescribed anticipating either synergism or one to act as an adjuvant for the other. Covidex was the most recommended and prescribed HM by participants possibly because very many people who had used it had reported exceptional positive outcomes, and it had been approved by the National Drug authority. This corelated with the respondents' determinants of recommending a specific HM brand, whereby" positive outcome reports from patients following use of a particular $\mathrm{HM}$ brand" and "the drug being of approved efficacy" were the major factors cited. This could imply that continued research to approve more HMs may result in their increased prescription and use in the country.

Testing positive for COVID-19 was associated with increased chances of using HM and those with good perception and positive attitude were likely to recommend a HM for friends and relatives. Similarly, studies in Turkey [23] and Nigeria [31] revealed that HP students were more likely to recommend CAMs they were knowledgeable and had positive attitude about to friends and patients. Social media was the major source of awareness for HM use in COVID-19 treatment to majority (68.8\%) of participants. This has been similarly reported among HP students from Palestine [19] Sierra Leon [24] and German [28]. Therefore, social media seems to be a common source of information in this century even when its reliability remains questionable.

Our study has some few limitations. First, the sample size is relatively low compared to the total number of students in these universities due to low responses of online studies since it wasn't incentivized. Sampling bias due to convenience sampling used in the study may limit the representativeness of the study. However, our study provides results from a large cross section of students with responses from at least each of the 12 medical schools in the country and variable programs of study, therefore the results can be generalized. The response rate of $62 \%$ is relatively significant to represent the pre-determined sample size. Sending daily reminders to the eligible participants on the targeted WhatsApp groups lessened possible response bias associated with online surveys.

\section{Conclusion}

Generally, the perception and attitude of HP students towards HM use in treatment of COVID-19 was poor. Despite this negative attitude, 7 in every $10 \mathrm{HP}$ students still advise a friend or relative to Use HM for covid-19 treatment and 9 in every 10 students recommend the HM to be used in combination with WM. A HM brand is more likely to be 
recommended if it produces positive treatment outcome reports from patients and if it is of approved efficacy by the national drug authority.

Students rely so much on social media for information yet it's not an authentic source of knowledge and majority think it is important to include HM training in their study curricula. We recommend the incorporation of HM use courses in the Ugandan medical schools' curricula for clearer patient guidance and better treatment outcomes.

\section{Declarations}

\section{Ethical Consideration}

This study was approved by the Mulago Hospital Research and Ethics Committee (MH-REC) study protocol MREC 2124. Mulago Hospital is the teaching hospital for Makerere University College of health sciences, and its Research and Ethics Committee board is one of those bodies authorized to approve any research done by Makerere University Medical students. Participation in the study was entirely voluntary and the participants were required to consent by clicking on the "I accept to participate" button at the end of the consent statement on the Google form before starting to answer the questions. The study was conducted while observing the declaration of Helsinki.

\section{Consent for publication}

Not applicable

\section{Availability of data and materials}

The datasets used and/or analyzed during the current study are available from the corresponding author on reasonable request.

\section{Competing interests}

The authors declare that they have no competing interests.

\section{Funding}

This study was not funded.

\section{Authors' contributions}

All the authors Blaise Kiyimba (BK), Andrew Marvin Kanyike (AMK), Nelson Ssewante (NS), Racheal Nalunkuma (RN), Phillip Musoke (PM), Linda Atulinda (LA), Claire Namuwaya (CN), Nicholas Kisaakye Wamala (NKW), Teddy Onyait (TO), Ramona Noeline Aringo (RNA), Hussein Kato (HK), Ignatius Asasira (IA), and Felix Bongomin (FB) made substantial contributions towards this work. BK, AMK, RN, PM, HK, and TO conceptualized and designed the study, BK, AMK, RN, LA, CN, NKW, RNA and IA collected data, BK and NS analyzed the data. All authors participated in drafting the manuscript and FB critically revised the article for final important intellectual content. All the authors agreed to submit the work to this journal and agree to be accountable for all aspects of this work.

\section{Acknowledgement}

The Authors are so grateful for the following people who assisted them in the data collection process: Johnbreubf Murungi, Stuart Kitandwe, Davis Banturaki, Kasekende Fulugensio, and Oscar Mwemeke from Makerere University, 
Hamiidah Nakyanzi from Lira University and Derrick Malinga, Faith Kwagala, Caroline Ashaba, Barbra Ainomugisha from Mbarara University of Science and Technology. We also thank Mr. Kajjimu Jonathan for his technical assistance. We thank all participants for their time and internet data spared to respond to our questionnaire.

\section{References}

1. Haque, Mainul The COVID-19 Pandemic - A Global Public Health Crisis: A Brief Overview Regarding Pharmacological Interventions. Pesquisa Brasileira em Odontopediatria e Clínica Integrada [online]. 2020, v. 20, suppl 1 [Accessed 4 September 2021],e0146. Available from: <https://doi.org/10.1590/pboci.2020.137>. Epub 31 Aug 2020. ISSN 1983-4632. https://doi.org/10.1590/pboci.2020.137.

2. Hadeel Alkofide, Abdullah Almohaizeie, Sara Almuhaini, Bashayer Alotaibi, Khalid M. Alkharfy, Tocilizumab and Systemic Corticosteroids in the Management of Patients with COVID-19: A Systematic Review and MetaAnalysis, International Journal of Infectious Diseases, Volume 110,2021,Pages320329,ISSN12019712,https://doi.org/10.1016/j.ijid.2021.07.021. (https://www.sciencedirect.com/science/article/pii/S1201971221005786)

3. Zarębska-Michaluk D, Jaroszewicz J, Rogalska M, Martonik D, Pabjan P, Berkan-Kawińska A, Bolewska B, OczkoGrzesik B, Kozielewicz D, Tudrujek-Zdunek M, Kowalska J, Moniuszko-Malinowska A, Kłos K, Rorat M, Leszczyński P, Piekarska A, Polańska J, Flisiak R. Effectiveness of Tocilizumab with and without Dexamethasone in Patients with Severe COVID-19: A Retrospective Study. J Inflamm Res.2021;14:3359-3366 https://doi.org/10.2147/JIR.S322645

4. https://www.fda.gov/emergency-preparedness-and-response/coronavirus-disease-2019-covid-19/covid-19vaccines.

5. Chaachouay N, Douira A, Zidane L. COVID-19, prevention and treatment with herbal medicine in the herbal markets of Salé Prefecture, North-Western Morocco. Eur J Integr Med. 2021 Feb;42:101285. doi: 10.1016/j.eujim.2021.101285. Epub 2021 Jan 8. PMID: 33520016; PMCID: PMC7836426.

6. Ang L, Song E, Lee HW, Lee MS. Herbal Medicine for the Treatment of Coronavirus Disease 2019 (COVID-19): A Systematic Review and Meta-Analysis of Randomized Controlled Trials. J Clin Med. 2020 May 23;9(5):1583. doi: 10.3390/jcm9051583. PMID: 32456123; PMCID: PMC7290825.

7. Chan KW, Wong VT, Tang SCW. COVID-19: An Update on the Epidemiological, Clinical, Preventive and Therapeutic Evidence and Guidelines of Integrative Chinese-Western Medicine for the Management of 2019 Novel Coronavirus Disease. Am J Chin Med. 2020;48(3):737-762. doi: 10.1142/S0192415X20500378. Epub 2020 Mar 13. PMID: 32164424.

8. Liu J, Manheimer E, Shi Y, Gluud C. Chinese herbal medicine for severe acute respiratory syndrome: a systematic review and meta-analysis. J Altern Complement Med. 2004 Dec;10(6):1041-51. doi: 10.1089/acm.2004.10.1041. PMID: 15674000.

9. Luo H, Tang QL, Shang YX, Liang SB, Yang M, Robinson N, Liu JP. Can Chinese Medicine Be Used for Prevention of Corona Virus Disease 2019 (COVID-19)? A Review of Historical Classics, Research Evidence and Current Prevention Programs. Chin J Integr Med. 2020 Apr;26(4):243-250. doi: 10.1007/s11655-020-3192-6. Epub 2020 Feb 17. PMID: 32065348; PMCID: PMC7088641.

10. Gao LQ, Xu J, Chen SD. In Silico Screening of Potential Chinese Herbal Medicine Against COVID-19 by Targeting SARS-CoV-2 3CLpro and Angiotensin Converting Enzyme II Using Molecular Docking. Chin J Integr Med. 2020 Jul;26(7):527-532. doi: 10.1007/s11655-020-3476-x. Epub 2020 Jul 6. PMID: 32632717; PMCID: PMC7338104. 
11. YQ Wu, L Zou, X Yu, D Sun, SB Li, L Tang, JR Yang, XY Chen, YG Wu, H Fang : Clinical effects of integrated traditional Chinese and western medicine on COVID-19: a systematic reviewShanghai J. Tradit. Chin. Med, 1-8, 2020

12. Zhan Z.L., Liu J., Yang W., Wang Y.G., Ruan L.G., Huang P., Guo L.P., Bian Y.J., Chen S.P., Chen Y., et al. Exploratory Study on Evaluation Criteria of Chinese Medicine Treatment of New Coronavirus Pneumonia Based on Case Analysis. [(accessed on 22 May 2020)];J. Tradit. Chin. Med. $2020: 1-11$. Available online: http://kns.cnki.net/kcms/detail/11.2166.R.20200312.0949.002.html.

13. Fan AY, Gu S, Alemi SF; Research Group for Evidence-based Chinese Medicine. Chinese herbal medicine for COVID-19: Current evidence with systematic review and meta-analysis. J Integr Med. 2020 Sep;18(5):385-394. doi: 10.1016/j.joim.2020.07.008. Epub 2020 Jul 31. PMID: 32792254; PMCID: PMC7834293.

14. Uganda approves use of local herbal COVID-19 drug"https://www.aa.com.tr/en/africa/uganda-approves-use-oflocal-herbal-covid-19-drug/2289365\#. Accessed 3rd August 2021.

15. Covidex out of stock in city pharmacies | Daily Monitor" https://www.monitor.co.ug/uganda/news/national/covidex-out-of-stock-in-city-pharmacies-3464470? view=htmlamp . Accessed $3^{\text {rd }}$ August 2021.

16. "Why medics can't administer Covidex for Covid-19 patients" https://www.independent.co.ug/why-medics-cantadminister-covidex-for-covid-19-patients/ . Accessed $3^{\text {rd }}$ August 2021.

17. https://visiongroup.co.ug/supplements/2020/01/23/higher-education-from-one-to53universities/\#: :text=From\%20one\%20public\%20university\%20that,them\%20public\%20and\%2044\%20private. Accessed $2^{\text {nd }}$ August 2021.

18. Amna Abdullah Alotiby, Laila Naif Al-Harbi, Prevalence of using herbs and natural products as a protective measure during the COVID-19 pandemic among the Saudi population: an online cross-sectional survey,Saudi Pharmaceutical Journal,Volume 29, Issue5 ,2021, Pages410-417, ISSN 1319-

0164,https://doi.org/10.1016/j.jsps.2021.04.001

19. Samara AM, Barabra ER, Quzaih HN, Zyoud SH. Use and acceptance of complementary and alternative medicine among medical students: a cross sectional study from Palestine. BMC Complement Altern Med. 2019 Apr 2;19(1):78. doi: 10.1186/s12906-019-2492-x. PMID: 30940118; PMCID: PMC6444598.

20. Liu J, Manheimer E, Shi Y, Gluud C. Chinese herbal medicine for severe acute respiratory syndrome: a systematic review and meta-analysis. J Altern Complement Med. 2004;10: 1041-51. doi:10.1089/acm.2004.10.1041

21. Saha BL, Seam MOR, Islam MM, Das A, Ahamed SK, Karmakar P, Islam MF, Kundu SK. General perception and self-practice of complementary and alternative medicine (CAM) among undergraduate pharmacy students of Bangladesh. BMC Complement Altern Med. 2017 Jun 14;17(1):314. doi: 10.1186/s12906-017-1832-y. PMID: 28615021; PMCID: PMC5471669.

22. Harris IM, Kingston RL, Rodriguez R, Choudary V. Attitudes towards complementary and alternative medicine among pharmacy faculty and students. Am J Pharm Educ. 2006 Dec 15;70(6):129. doi: 10.5688/aj7006129. PMID: 17332855; PMCID: PMC1803695.

23. Akan H, Izbirak G, Kaspar EÇ, Kaya ÇA, Aydin S, Demircan N, et al. Knowledge and attitudes towards complementary and alternative medicine among medical students in Turkey. BMC Complement Altern Med. 2012;12: 115. doi:10.1186/1472-6882-12-115

24. James PB, Bah AJ. Awareness, use, attitude and perceived need for Complementary and Alternative Medicine (CAM) education among undergraduate pharmacy students in Sierra Leone: a descriptive cross-sectional survey. 
BMC Complement Altern Med. 2014 Nov 8;14:438. doi: 10.1186/1472-6882-14-438. PMID: 25380656; PMCID: PMC4236455.

25. Ang L, Song E, Lee HW, Lee MS. Herbal Medicine for the Treatment of Coronavirus Disease 2019 (COVID-19): A Systematic Review and Meta-Analysis of Randomized Controlled Trials. J Clin Med. 2020;9: 1583. doi:10.3390/jcm9051583

26. Chan KW, Wong VT, Tang SCW. COVID-19: An Update on the Epidemiological, Clinical, Preventive and Therapeutic Evidence and Guidelines of Integrative Chinese-Western Medicine for the Management of 2019 Novel Coronavirus Disease. Am J Chin Med. 2020;48: 737-762. doi:10.1142/S0192415X20500378

27. Hussain S, Malik F, Hameed A, Ahmed S, Riaz H, Abbasi N, Malik M. Pakistani pharmacy students' perception about complementary and alternative medicine. Am J Pharm Educ. 2012 Mar 12;76(2):21. doi:

10.5688/ajpe76221. PMID: 22438593; PMCID: PMC3305930.

28. Münstedt K, Harren H, Von Georgi R, Hackethal A. Complementary and alternative medicine: Comparison of current knowledge, attitudes and interest among German medical students and doctors. Evidence-based Complement Altern Med. 2011;2011. doi:10.1093/ecam/nen079

29. Abbott RB, Hui KK, Hays RD, Mandel J, Goldstein M, Winegarden B, et al. Medical student attitudes toward complementary, alternative and integrative medicine. Evidence-based Complement Altern Med. 2011;2011. doi:10.1093/ecam/nep195

30. Kanyike, A.M., Olum, R., Kajjimu, J. et al. Acceptance of the coronavirus disease-2019 vaccine among medical students in Uganda. Trop Med Health 49, 37 (2021). https://dKanyike, A.M., Olum, R., Kajjimu, J. et al.Acceptance of the coronavirus disease-2019 vaccine among medical students in Uganda. Trop Med Health 49, 37 (2021). https://doi.org/10.1186/s41182-021-00331-1

31. Enwere 00. Herbs in orthodox practice: a view by medical students. Afr J Tradit Complement Altern Med. 2009 Mar 7;6(2):203-6. doi: 10.4314/ajtcam.v6i2.57092. PMID: 20209013; PMCID: PMC2816560.

\section{Tables}

Table 1: Sociodemographic characteristics of participants and how they influence perception and attitude towards herbal medicine use 


\begin{tabular}{|c|c|c|c|c|c|c|c|}
\hline \multirow{3}{*}{ Variable } & \multirow{3}{*}{$\begin{array}{c}\text { All } \\
(\mathrm{N}=350)\end{array}$} & \multicolumn{3}{|c|}{ Perception } & \multicolumn{3}{|c|}{ Attitude } \\
\hline & & $\begin{array}{c}\text { Good, } \mathrm{n} \\
\text { (\%) }\end{array}$ & $\begin{array}{l}\text { Poor, } \mathrm{n} \\
\text { (\%) }\end{array}$ & $\begin{array}{c}\mathrm{p}- \\
\text { value }\end{array}$ & $\begin{array}{c}\text { Positive, } \\
\text { n (\%) }\end{array}$ & $\begin{array}{c}\text { Negative, } \\
\text { n (\%) }\end{array}$ & p-value \\
\hline & & $54(15)$. & \begin{tabular}{|l|}
$296(84.6)$ \\
\end{tabular} & & $129(36.9)$ & $221(63.1)$ & \\
\hline Mean scores & & \multicolumn{3}{|c|}{$54.9(\mathrm{SD}=21.1)$} & \multicolumn{3}{|c|}{$72(\mathrm{SD}=13.6)$} \\
\hline $\begin{array}{l}\text { Age group } \\
18-25 \\
26-35 \\
>35\end{array}$ & $\begin{array}{c}268(76.6) \\
78(22.3) \\
4(1.1)\end{array}$ & $\begin{array}{c}47(17.5) \\
7(9) \\
0(0)\end{array}$ & \begin{tabular}{|c|}
$221(82.5)$ \\
$71(91)$ \\
$4(100)$
\end{tabular} & 0.165 & $\begin{array}{c}106(39.6) \\
22(28.2) \\
1(25)\end{array}$ & $\begin{array}{c}162(60.4) \\
56(71.8) \\
3(75)\end{array}$ & 0.148 \\
\hline $\begin{array}{l}\text { Sex } \\
\text { Female } \\
\text { Male }\end{array}$ & $\begin{array}{l}127(36.3) \\
223(63.7)\end{array}$ & $\begin{array}{l}21(16.5) \\
33(14.8)\end{array}$ & $\begin{array}{l}106(83.5) \\
190(85.2)\end{array}$ & 0.665 & $\begin{array}{c}47(37) \\
82(36.8)\end{array}$ & $\begin{array}{c}80(63) \\
141(63.2)\end{array}$ & 0.965 \\
\hline $\begin{array}{l}\text { Religion } \\
\text { Anglican } \\
\text { Born again } \\
\text { Catholic } \\
\text { Moslem } \\
\text { Others a } \\
\text { Seventh Day Adventist }\end{array}$ & $\begin{array}{c}113(32.3) \\
72(20.6) \\
111(31.7) \\
38(10.9) \\
6(1.7) \\
10(2.9)\end{array}$ & $\begin{array}{c}18(15.9) \\
14(19.4) \\
15(13.5) \\
4(10.5) \\
1(16.7) \\
2(20) \\
\end{array}$ & $\begin{array}{c}95(84.1) \\
58(80.6) \\
96(86.5) \\
34(89.5) \\
5(83.3) \\
8(80)\end{array}$ & 0.781 & $\begin{array}{c}44(38.9) \\
32(44.4) \\
39(35.1) \\
8(21.1) \\
2(33.3) \\
4(40)\end{array}$ & $\begin{array}{c}69(61.1) \\
40(55.6) \\
72(64.9) \\
30(78.9) \\
4(66.7) \\
6(60)\end{array}$ & 0.254 \\
\hline $\begin{array}{l}\text { Residence } \\
\text { Rural } \\
\text { Urban }\end{array}$ & $\begin{array}{l}159(45.4) \\
191(54.6)\end{array}$ & $\begin{array}{l}30(18.9) \\
24(12.6) \\
\end{array}$ & $\begin{array}{l}129(81.1) \\
167(87.4) \\
\end{array}$ & 0.104 & $\begin{array}{l}59(37.1) \\
70(36.6) \\
\end{array}$ & $\begin{array}{l}100(62.9) \\
121(63.4)\end{array}$ & 0.93 \\
\hline $\begin{array}{l}\text { University } \\
\text { Busitema University } \\
\text { Kampala International } \\
\text { university } \\
\text { Lira university } \\
\text { Makerere University } \\
\text { Mbarara University of } \\
\text { Science and Technology } \\
\text { Others b }\end{array}$ & $\begin{array}{c}50(14.3) \\
60(17.1) \\
19(5.4) \\
144(41.1) \\
47(13.4) \\
30(8.6) \\
\end{array}$ & $\begin{array}{c}5(10) \\
9(15) \\
3(15.8) \\
24(16.7) \\
10(21.3) \\
3(10) \\
\end{array}$ & \begin{tabular}{|c|}
$45(90)$ \\
$51(85)$ \\
\\
$16(84.2)$ \\
$120(83.3)$ \\
$37(78.7)$ \\
$27(90)$ \\
\end{tabular} & 0.69 & $\begin{array}{c}21(42) \\
19(31.7) \\
9(47.4) \\
47(32.6) \\
21(44.7) \\
12(40) \\
\end{array}$ & $\begin{array}{c}29(58) \\
41(68.3) \\
10(52.6) \\
97(67.4) \\
26(55.3) \\
18(60) \\
\end{array}$ & 0.463 \\
\hline $\begin{array}{l}\text { Course/Program } \\
\text { Bachelor in Dental surgery } \\
\text { Bachelor in Nursing/ } \\
\text { Midwifery } \\
\text { Bachelor in Pharmacy } \\
\text { Bachelors in Medicine and } \\
\text { surgery } \\
\text { Others }^{c}\end{array}$ & $\begin{array}{c}8(2.3) \\
47(13.4) \\
\\
31(8.9) \\
234(66.9) \\
30(8.6)\end{array}$ & $\begin{array}{c}0(0) \\
6(12.8) \\
8(25.8) \\
35(15) \\
5(16.7)\end{array}$ & $\begin{array}{c}8(100) \\
41(87.2) \\
23(74.2) \\
199(85) \\
25(83.3)\end{array}$ & 0.424 & $\begin{array}{c}3(37.5) \\
18(38.3) \\
\\
21(67.7) \\
69(29.5) \\
18(60)\end{array}$ & $\begin{array}{c}5(62.5) \\
29(61.7) \\
\\
10(32.3) \\
165(70.5) \\
12(40)\end{array}$ & $<0.001$ \\
\hline $\begin{array}{l}\text { Year of study } \\
\text { Year } 1 \\
\text { Year } 2 \\
\text { Year } 3 \\
\text { Year } 4 \\
\text { Year } 5\end{array}$ & $\begin{array}{l}50(14.3) \\
48(13.7) \\
72(20.6) \\
92(26.3) \\
88(25.1)\end{array}$ & $\begin{array}{c}16(32) \\
8(16.7) \\
5(6.9) \\
16(17.4) \\
9(10.2) \\
\end{array}$ & $\begin{array}{c}34(68) \\
40(83.3) \\
67(93.1) \\
76(82.6) \\
79(89.8)\end{array}$ & 0.003 & $\begin{array}{c}25(50) \\
22(45.8) \\
28(38.9) \\
36(39.1) \\
18(20.5)\end{array}$ & $\begin{array}{c}25(50) \\
26(54.2) \\
44(61.1) \\
56(60.9) \\
70(79.5)\end{array}$ & 0.003 \\
\hline
\end{tabular}

a. Other religions included Jehovah's witnesses, traditionalists, no religious affiliation. Other universities included Gulu, IUIU, Kabale, Muni, UCU, King Ceasor and Soroti. ...... c. Other courses included Bachelors in public health/Environmental health, Medical Radiography, Anesthesia, Diploma in Clinical medicine, Diploma in Pharmacy. 
Table 2: Multivariate analysis of the factors associated with good perception and positive attitudes towards herbal medicine use among participants

\begin{tabular}{|l|c|l|l|l|}
\hline \multirow{2}{*}{ Variable } & \multicolumn{2}{|c|}{ Perception } & \multicolumn{2}{c|}{ Attitude } \\
\cline { 2 - 5 } & aOR (95\% CI) & P-value & aOR (95\% CI) & P-value \\
\hline Age group & & & & \\
$26-25$ & Reference & - & - & - \\
$>35$ & $0.5(0.2-1.2)$ & 0.108 & $0.7(0.4-1.4)$ & 0.351 \\
Sex & 1.0 & & $0.4(0.0-5.0)$ & 0.499 \\
Male & Reference & & & \\
Female & $1.1(0.6-2.1)$ & 0.802 & $0.8(0.5-1.4)$ & 0.454 \\
\hline Religion & & & & \\
Anglican & Reference & & & \\
Catholic & $0.9(0.4-1.9)$ & 0.748 & $0.9(0.5-1.7)$ & 0.823 \\
Born Again & $1.6(0.7-3.7)$ & 0.280 & $1.4(0.7-2.6)$ & 0.348 \\
Moslems & $0.8(0.2-2.9)$ & 0.789 & $0.5(0.2-1.3)$ & 0.14 \\
SDA & $1.6(0.3-9.7)$ & 0.619 & $0.9(0.2-3.7)$ & 0.841 \\
Others & $1.5(0.1-14.8)$ & 0.748 & $1.1(0.2-6.7)$ & 0.956 \\
\hline Residence & & & & \\
Urban & Reference & & & \\
Rural & $1.8(0.9-3.4)$ & 0.081 & $1.1(0.7-1.7)$ & 0.785 \\
\hline Year of study & & & & \\
Year 5 & Reference & & & \\
Year 4 & $1.4(0.5-3.6)$ & 0.511 & $1.8(0.8-3.7)$ & 0.136 \\
Year 3 & $0.5(0.1-1.6)$ & 0.237 & $1.5(0.7-3.4)$ & 0.301 \\
Year 2 & $1.3(0.4-4.0)$ & 0.684 & $2(0.8-4.8)$ & 0.113 \\
Year 1 & $2.9(1.1-8.1)$ & 0.037 & $2.7(1.2-6.3)$ & 0.019 \\
\hline Course & & & & \\
MBChB & Reference & & & \\
BDS & 1.0 & & $2.1(0.4-9.8)$ & 0.369 \\
BNUR & $0.7(0.3-2.0)$ & 0.532 & $1.2(0.6-2.5)$ & 0.577 \\
BPHAR & $2.1(0.8-5.6)$ & 0.146 & $4.2(1.8-9.9)$ & 0.001 \\
Others & $1.1(0.3-3.4)$ & 0.899 & $3.1(1.3-7.3)$ & 0.009 \\
\hline
\end{tabular}

Table 3: Participants' practices and use of herbal medicine 


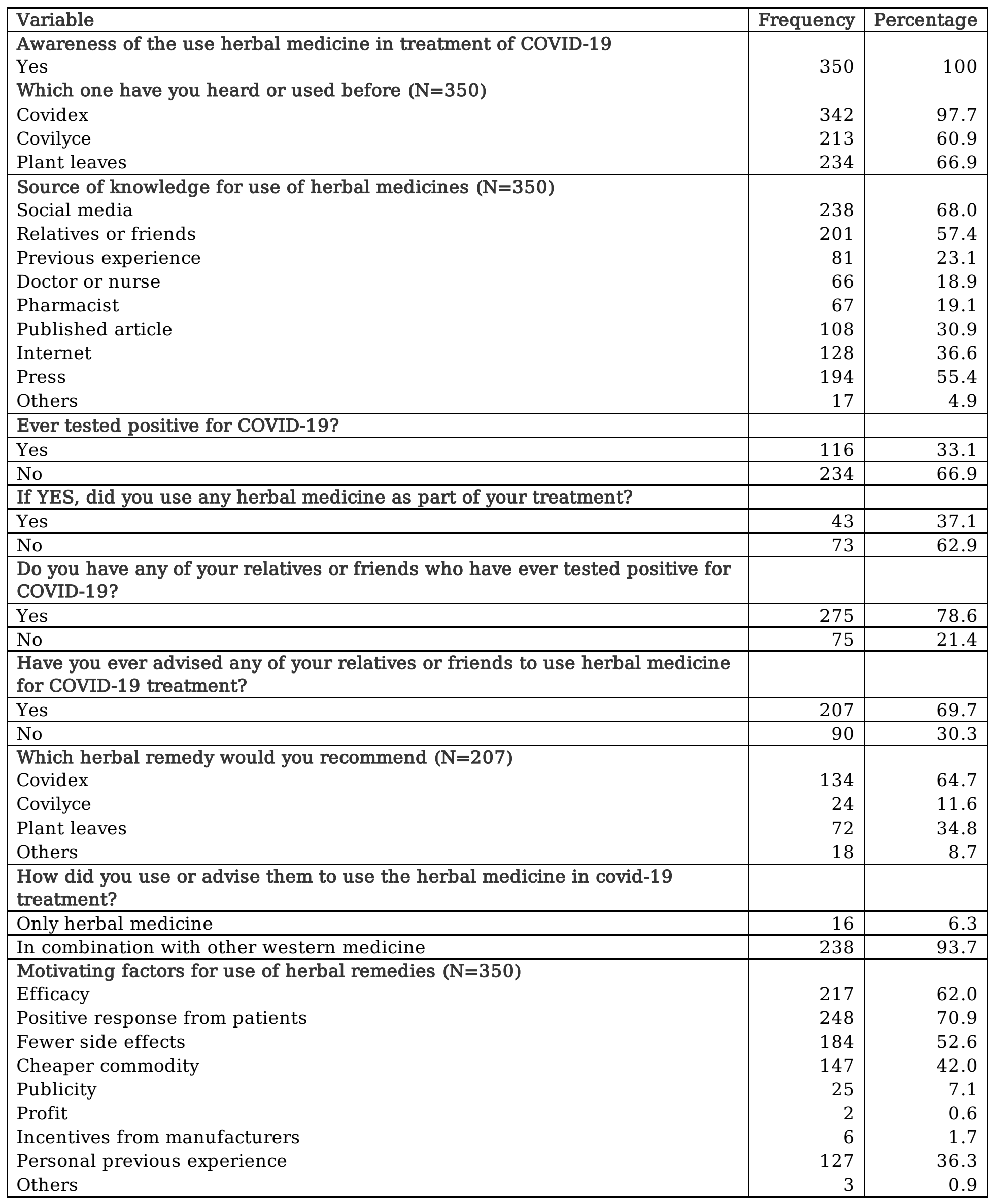


Table 4: Factors associated with use of herbal medicines among health care students in Uganda.

\begin{tabular}{|c|c|c|c|c|}
\hline \multirow[t]{2}{*}{ Variable, $\mathrm{N}=305$} & \multicolumn{2}{|c|}{$\begin{array}{c}\text { Personal use of herbal } \\
\text { medicine }\end{array}$} & \multicolumn{2}{|c|}{$\begin{array}{l}\text { Advise for use of herbal } \\
\text { medicine }\end{array}$} \\
\hline & n (\%) & p-value & n (\%) & $p$-value \\
\hline $\begin{array}{l}\text { Age group } \\
18-25 \\
26-35 \\
36-45 \\
\end{array}$ & $\begin{array}{l}30(8.6) \\
13(3.7) \\
0(0)\end{array}$ & 0.465 & $\begin{array}{l}157(44.9) \\
47(13.4) \\
3(0.9) \\
\end{array}$ & 0.968 \\
\hline $\begin{array}{l}\text { Sex } \\
\text { Female } \\
\text { Male }\end{array}$ & $\begin{array}{l}17(4.9) \\
26(7.4)\end{array}$ & 0.063 & $\begin{array}{l}82(23.4) \\
125(35.7)\end{array}$ & 0.509 \\
\hline $\begin{array}{l}\text { Religion } \\
\text { Anglican } \\
\text { Born again } \\
\text { Catholic } \\
\text { Moslem } \\
\text { Others } \\
\text { SDA }\end{array}$ & $\begin{array}{l}15(4.3) \\
7(2) \\
15(4.3) \\
6(1.7) \\
0(0) \\
0(0)\end{array}$ & 0.728 & $\begin{array}{l}68(19.4) \\
46(13.1) \\
63(18) \\
19(5.4) \\
2(0.6) \\
9(2.6)\end{array}$ & 0.082 \\
\hline $\begin{array}{l}\text { Residence } \\
\text { Rural } \\
\text { Urban }\end{array}$ & $\begin{array}{l}19(5.4) \\
24(6.9)\end{array}$ & 0.971 & $\begin{array}{l}91(26) \\
116(33.1)\end{array}$ & 0.799 \\
\hline $\begin{array}{l}\text { University } \\
\text { Busitema } \\
\text { KIU } \\
\text { Lira } \\
\text { Makerere } \\
\text { Mbarara } \\
\text { Others } \\
\end{array}$ & $\begin{array}{l}4(1.1) \\
8(2.3) \\
3(0.9) \\
19(5.4) \\
3(0.9) \\
6(1.7)\end{array}$ & 0.829 & $\begin{array}{l}27(7.7) \\
41(11.7) \\
11(3.1) \\
83(23.7) \\
26(7.4) \\
19(5.4) \\
\end{array}$ & 0.635 \\
\hline $\begin{array}{l}\text { Course/Program } \\
\text { Bachelor in Dental surgery } \\
\text { Bachelor in Nursing/ Midwifery } \\
\text { Bachelor in Pharmacy } \\
\text { Bachelors in Medicine and } \\
\text { surgery } \\
\text { Others }\end{array}$ & $\begin{array}{l}1(0.3) \\
5(1.4) \\
6(1.7) \\
28(8) \\
3(0.9)\end{array}$ & 0.541 & $\begin{array}{l}5(1.4) \\
25(7.1) \\
25(7.1) \\
133(38) \\
19(5.4)\end{array}$ & 0.074 \\
\hline $\begin{array}{l}\text { Year of study } \\
\text { Year } 1 \\
\text { Year } 2 \\
\text { Year } 3 \\
\text { Year } 4 \\
\text { Year } 5\end{array}$ & $\begin{array}{l}8(2.3) \\
1(0.3) \\
11(3.1) \\
9(2.6) \\
14(4)\end{array}$ & 0.227 & $\begin{array}{l}33(9.4) \\
29(8.3) \\
43(12.3) \\
56(16) \\
46(13.1)\end{array}$ & 0.009 \\
\hline $\begin{array}{l}\text { Ever tested positive for COVID-19 } \\
\text { Yes } \\
\text { No }\end{array}$ & $\begin{array}{l}3(0.9) \\
40(11.4)\end{array}$ & $<0.001$ & $\begin{array}{l}47(13.4) \\
160(45.7)\end{array}$ & 0.036 \\
\hline $\begin{array}{l}\text { Perception } \\
\text { Good } \\
\text { Poor }\end{array}$ & $\begin{array}{l}7(2) \\
36(10.3)\end{array}$ & 0.409 & $\begin{array}{l}41(11.7) \\
166(47.4)\end{array}$ & 0.001 \\
\hline $\begin{array}{l}\text { Attitude } \\
\text { Positive } \\
\text { Negative }\end{array}$ & $\begin{array}{l}19(5.4) \\
24(6.9)\end{array}$ & 0.126 & $\begin{array}{l}97(27.7) \\
110(31.4)\end{array}$ & $<0.001$ \\
\hline
\end{tabular}


Table 5: Predictors of use of herbal medicines among health care students in Uganda

\begin{tabular}{|c|c|c|c|c|}
\hline \multirow[t]{2}{*}{ Variable } & \multicolumn{2}{|c|}{$\begin{array}{l}\text { Personal use of herbal } \\
\text { medicine }\end{array}$} & \multicolumn{2}{|c|}{$\begin{array}{l}\text { Advise for use of herbal } \\
\text { medicine }\end{array}$} \\
\hline & aOR $(95 \% \mathrm{CI})$ & p-value & aOR (95\% CI) & p-value \\
\hline $\begin{array}{l}\text { Sex } \\
\text { Male } \\
\text { Female }\end{array}$ & $\begin{array}{c}\text { Reference } \\
0.9(0.2-3.4)\end{array}$ & $\begin{array}{c}- \\
0.906\end{array}$ & $1.1(0.6-2.1)$ & $\begin{array}{c}- \\
0.661\end{array}$ \\
\hline $\begin{array}{l}\text { Religion } \\
\text { Anglican } \\
\text { Born again } \\
\text { Catholic } \\
\text { Moslem } \\
\text { Others } \\
\text { SDA }\end{array}$ & $\begin{array}{c}\text { Reference } \\
0.7(0.2-2.9) \\
0.4(0.1-2.1) \\
1.6(0.2-11.1) \\
1 \\
1\end{array}$ & $\begin{array}{l}- \\
0.608 \\
0.271 \\
0.623\end{array}$ & $\begin{array}{c}- \\
1(0.5-2.0) \\
1.1(0.5-2.6) \\
0.9(0.3-2.2) \\
1 \\
0.2(0.0-1.2)\end{array}$ & $\begin{array}{l}- \\
0.993 \\
0.758 \\
0.738 \\
0.079\end{array}$ \\
\hline $\begin{array}{l}\text { Course/Program } \\
\text { Bachelor in Dental surgery } \\
\text { Bachelor in Nursing/ Midwifery } \\
\text { Bachelor in Pharmacy } \\
\text { Bachelors in Medicine and } \\
\text { surgery } \\
\text { Others }\end{array}$ & $\begin{array}{c}\text { Reference } \\
0.2(0.0-1.3) \\
0.8(0.2-4.1) \\
0.1(0.0-1.2) \\
2.1(0.3-13.3)\end{array}$ & $\begin{array}{c}- \\
0.093 \\
0.797 \\
0.066 \\
0.436\end{array}$ & $\begin{array}{c}- \\
1.1(0.5-2.3) \\
2.6(1.1-6.4) \\
2(0.7-5.5) \\
3.6(1.1-11.6)\end{array}$ & $\begin{array}{c}- \\
0.780 \\
0.035 \\
0.167 \\
0.032\end{array}$ \\
\hline $\begin{array}{l}\text { Year of study } \\
\text { Year } 5 \\
\text { Year } 4 \\
\text { Year } 3 \\
\text { Year } 2 \\
\text { Year } 1\end{array}$ & $\begin{array}{c}\text { Reference } \\
0.4(0.0-8.2) \\
2.2(0.2-19.3) \\
2.6(0.3-19.7) \\
1(0.1-12.3)\end{array}$ & $\begin{array}{c}- \\
0.519 \\
0.486 \\
0.350 \\
0.977\end{array}$ & $\begin{array}{c}- \\
2.9(0.3-30.4) \\
0.8(0.3-1.9) \\
1.7(0.5-6.6) \\
1.2(0.4-4.0)\end{array}$ & $\begin{array}{c}- \\
0.375 \\
0.570 \\
0.425 \\
0.739\end{array}$ \\
\hline $\begin{array}{l}\text { Ever tested positive for COVID-19 } \\
\text { No } \\
\text { Yes }\end{array}$ & $\begin{array}{c}\text { Reference } \\
1.6(0.3-10.2) \\
\end{array}$ & 0.604 & $2.7(0.9-7.9)$ & $\begin{array}{c}- \\
0.064 \\
\end{array}$ \\
\hline $\begin{array}{l}\text { Perception } \\
\text { Poor } \\
\text { Good }\end{array}$ & $\begin{array}{c}\text { Reference } \\
2.4(0.7-8.5)\end{array}$ & 0.188 & $3.3(1.6-6.5)$ & $\begin{array}{c}- \\
0.001\end{array}$ \\
\hline $\begin{array}{l}\text { Attitude } \\
\text { Negative } \\
\text { Positive }\end{array}$ & $\begin{array}{c}\text { Reference } \\
63.7(12.8-316.4)\end{array}$ & $\begin{array}{c}- \\
<0.001\end{array}$ & $\begin{array}{c}- \\
2.7(1.2-5.9)\end{array}$ & $\begin{array}{c}- \\
0.013\end{array}$ \\
\hline
\end{tabular}

